\title{
The Application of Benthic Diatoms in Water Quality Assessment in Lepenci River Basin, Kosovo
}

\author{
Pajtim Bytyqi', Prespa Ymeri², Marton Czikkely², Osman Fetoshi ${ }^{3^{*}}$, \\ Albona Shala-Abazi ${ }^{5}$, Murtezan Ismaili', Qëndrim Ramshaj ${ }^{4}$, Fadil Millaku ${ }^{6}$ \\ 1 South East European University, Faculty of Contemporary Sciences and Technologies, llindenska 335, Tetovo \\ Macedonia \\ 2 Climate Change Economics Research Centre, Faculty of Economics and Social Sciences, Szent István \\ University, 2100 Gödöllö, Hungary \\ 3 University of Applied Sciences, Faculty of Tourism and Environment, University 70000, Ferizaj, Kosovo \\ ${ }^{4}$ Department of Biology, Faculty of Mathematics and Natural Sciences, University of Prishtina, Mother Teresa \\ 5, Prishtina 10000, Kosovo \\ 5 Faculty of Management in Tourism, Hotels and Environment, University "Haxhi Zeka", Str. UÇK 30000 Pejë, \\ Kosova \\ ${ }^{6}$ University "Haxhi Zeka", Str."UÇK" 30000 Pejë, Kosova \\ * Corresponding author's e-mail: osmanfetoshi@hotmail.com
}

\begin{abstract}
During the study on the assessment of ecological status of the Lepenci river basin, epilithic diatoms were used. Via this methodology, the authors aimed to standardization the ecological assessment methodology and gradually make it applicable for all river basins of Kosovo. The authors relied on a hypothesis that the epilithic diatom communities can serve as a reliable ecological tool to evaluate the quality of flowing waters in Kosovo. Thirteen water quality indices (IBD, IPS, IDG, DESCY, SLA, IDSE, IDAP, EPID, CEE, WAT, TDI, IDP and SHE) were measured in eight sample-points. From the conducted qualitative analysis, the obtained results showed that the water quality varies from upper parts of the basin (SP1, SP2, SP3 \& SP4) characterized with higher water quality towards the lower parts (SP5, SP6 \& SP7) where water quality was of the 2nd class and finally in Hani i Elezit (SP8) where the index values showed that its water belongs to the 3 rd class. The samples were taken in to 8 sampling sites, in river during year (2017), the Navicula viridula species was the most dominant, along with Cocconeis placentula var. lineate and Diatoma vulgaris. In turn, between August and end of September, the following species were dominant ones: Craticula ambigua, Navicula hintzii, Navicula viridula and Rhoicosphenia abbreviata.
\end{abstract}

Keywords: diatoms; bioindicators; Lepenci; Kosovo; environmental control

\section{INTRODUCTION}

As a diverse group of unicellular algae, aquatic diatoms are well-known as biological indicators with high sensitivity and narrow tolerance of their individual species towards the altering environmental parameters such as $\mathrm{pH}$, salinity, nutrient availability as well as organic and inorganic pollution [Round 1993, Prygiel and Coste 1993, Soltanpour et al. 2011, Vasiljević 2014, Lobo et al. 2016, Antonelli et al. 2017]. In pursuit of correct manner to estimate the degradation of water bodies across the globe, scientists have developed several diatom-based indices such as IPS [Cemagref 1982], the TDI [Kelly et al. 1995] as well as BDI [Lenoir and Coste 1996]. The continuous and systematic use of these indices in all biomonitoring related programs in Europe within the European Water Framework Directive makes them very trustworthy and reliable for Kosovo (DKU 2000) and additionally points out that the biological indicators play an important role in the 
evaluation of the ecological status. Anyhow, large number of taxa that can be involved remains a problematic issue in using and analyzing diatoms as an biological indicator [Soltanpour et al. 2011, Dalu et al. 2016] that has been so far partially solved by using the indices that rely only on genera [Rumeau and Coste 1988, Rovira et al. 2012, Blanco et al. 2012]. Additionally, other authors [Àcs et al. 2004, Hassan and Shaawiat 2015, Srivastava et al. 2017, Bere and Tundisi 2010, BesseLototskaya et al. 2011, Jüttner et al. 2012] mention the required expertise on taxonomic treatment of this large and diverse group of aquatic organisms and their distributional patterns along streams that is directly interlinked with $\mathrm{pH}$, temperature, substrate type and light availability [Toman et al. 2014, Kahlert and Rašić 2015, Trobajo and Sullivan 2010] among other factors. So far, in the biomonitoring studies in Kosovo concerning the water quality issues, the diatom flora has been neglected and has therefore received little attention or no attention at all, even though it is well-known that they, in particular the freshwater species, constitute a major group of algae. Via this study, the authors aimed at assessing the diatom flora of the Lepenci river basin, representing an important step towards the general overview and assessment of all freshwater rivers and basins of Kosovo.

Diatoms are an important component of ecosystems because they are in high correlation with the environmental characteristics [Hill, et al., 2001]. They are a specialized, systematic group of algae occurring in almost all water ecosystems and other damp habitats. Diatoms are valuable indicators of the stream ecosystem conditions because they are relatively simple to collect, respond rapidly and predictably to the changes in stream chemistry and habitat quality, taxonomically diverse, have short regeneration times, and are ubiquitous, which allows for comparisons across geographic regions [Round 1991, van Dam et al. 1994, Leland 1995].

They are a systematic group used in assessment of water quality [Noga et al., 2014]. These organisms constitute one of the main dominant groups of periphytic algae in lotic systems and efficient indicators of environmental changes, since they respond sensitively to the physical and chemical changes of water quality [Winter and Duthie, 2000; Lobo et al., 2002].

Diatoms have been recognized as good indicators of water quality [Stevenson, 2014], Maznah and Omar [2010] revealed that the use of algae as bioindicators is important to identify the alteration of water quality in the freshwater ecosystems.

Especially, algae have been shown as a good indicator for the environmental stress assessment caused by nutrient pollutants (substances containing nitrogen and phosphorus).

The research on the diversity of diatomic algae and the determination of surface water quality, with the help of these bioindicators in Kosovo Rivers to date has been scarce.

\section{MATERIAL AND METHODS}

The Lepenci River basin is the main water catchment in the southeastern part of the Republic of Kosovo. The hydrographic network that discharges water in the Lepenci River covers an area of $653 \mathrm{~km}^{2}$ [KEPA, 2015], which is located in the territory of Kosovo, and which compared to the total area of Kosovo constitutes $5.98 \%$ thereof. The Lepenci River basin has its source in high mountainous areas at an altitude of $2212 \mathrm{~m}$ and is mainly fed by the water sources that flow into mountainous hills between the hydro-geologic formations in the upper permeable collector and watertight formations or floor hydro-geologic isolators at the bottom. The Lepenci River basin has a length of $50 \mathrm{~km}$ and average annual flow of $8.4 \mathrm{~m}^{3} / \mathrm{s}$ [KEPA, 2015]; it has a river bed with many meanders forming in its entire length a river trench which continues outside the territory of Kosovo. The average annual precipitation in the Lepenci River area is $912 \mathrm{~mm}$, whereas the effective precipitation is $469.8 \mathrm{~mm}$ with a coefficient of flow of 0.516 [KEPA, 2015].

The sampling was conducted during spring, summer and autumn, 2017, from 8 localities (S1S8), along the River basin of Lepenci. (Figure 1).

The authors collected the benthic diatoms by scraping with a toothbrush, preserving the material in $4 \%$ formalin.

Preparation and cleaning of the diatoms followed the CEN methodology (prEN 13946:2002) with $30 \%$ cold hydrogen peroxide $\left(\mathrm{H}_{2} \mathrm{O}_{2}\right), 37 \%$ hydrochloric acid $(\mathrm{HCl})$ to oxidize organic matter and clean the diatom frustule. Microscopic identification and analysis was performed with mounted digital camera (MotiCam 5+/5.0 MP). The following literature sources for determining the diatom species:[Lange-Bertalot 1993, LangeBertalot 2001, Cantonati et al. 2017, Krammer 


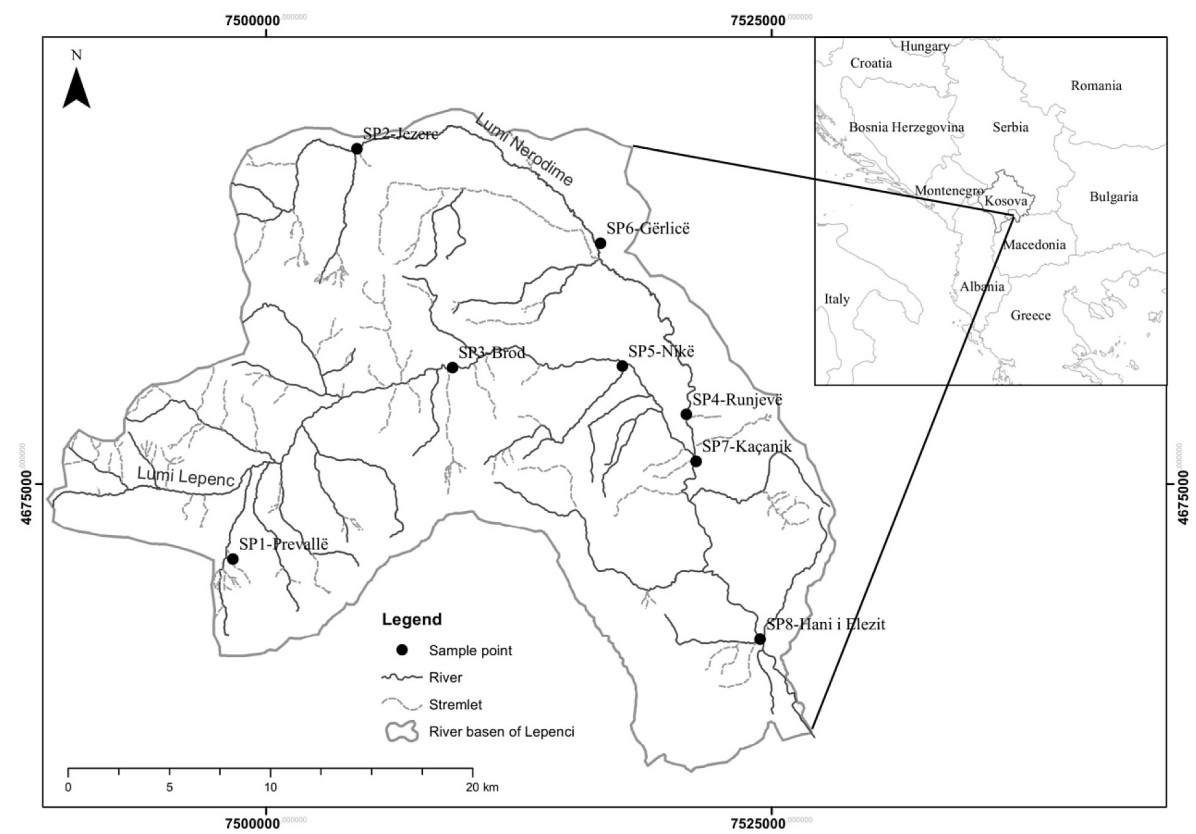

Figure 1. Location of investigated area

2010, 2012, 2013, Lange-Bertalot et al. 2011, Levkov et al. 2007, Levkov 2009, Levkov and Williams 2011, Levkov et al. 2016, Levkov et al. 2013, Pavlov et al. 2013]. Thirteen diatom indices, calculated based on the indicator values of the identified taxa using the OMNIDIA software [Lecointe et al. 1993] for the water quality assessment are: IBD [Prygiel and Coste 2000], IPS [Cemagref 1982], IDG [Prygiel and Coste 2000, Lecointe et al. 1993], Descy [Descy 1979], SLA [Sladecek 1986], IDSE [Leclercq and Lecointe 2008], IDAP [Prygiel et al. 2002], EPID [Dell' Uomo 2004], CEE [Descy and Coste 1991], WAT [Lecointe et al. 2003], TDI [Kelly et al. 1995], IDP [Gómez and Licursi 2001], SHE [Srivastava et al. 2017]. The scale values from 1 up to 20 were used.

Total species number, distribution and of species per locality, diversity of species - ShannonWiener diversity index $(H)$, Simpson diversity index (D), Margalef index, Menhinick index, species richness estimator (SChao 1) (a species richness estimator estimate the total number of species present in a community and is based upon the number of rare species (singleton and doubleton) found in a sample [Chao, 1984] and similarity index (Jaccard's similarity index -Ja) were calculated using ComEcoPaC - Community Ecology Parameter Calculator, Version 1 [http://prf.osu.cz/kbe/ dokumenty/sw/ComEcoPaC/ComEcoPaC.xls].

The analyses of physicochemical parameters were performed based on the ISO 5667-6 standard, which determines the principles to be applied in designing the programs in sample collection, the techniques of sample collection and the treatment of water samples from rivers and flows for the physical and chemical assessment [ISO, 2014]. The samples for water quality analysis were collected at the same time as the diatom samples. Environmental factors, including water temperature, $\mathrm{pH}$, dissolved oxygen (DO), electrical conductivity (EC), and total dissolved solids (TDS). The concentrations of silicate $\left(\mathrm{SiO}_{2}\right.$, $\left.\mathrm{mg} \cdot \mathrm{L}^{-1}\right)$, nitrate $\left(\mathrm{NO}_{3}^{-}, \mathrm{mg} \cdot \mathrm{L}^{-1}\right)$, orthophosphate $\left(\mathrm{PO}_{4}^{3-}, \mathrm{mg} \cdot \mathrm{L}^{-1}\right)$, ammonium $\left(\mathrm{NH}_{4}^{+}, \mathrm{mg} \cdot \mathrm{L}^{-1}\right)$, and sulfate $\left(\mathrm{SO}_{4}{ }^{-2}, \mathrm{mg} \cdot \mathrm{L}^{-1}\right)$.

\section{RESULTS AND DISCUSSION}

The results of water analysis are presented in Table 1 . The variation of temperature ranged between $8.5^{\circ} \mathrm{C}$ in $\mathrm{SP} 1$ (autumn) to $20.7^{\circ} \mathrm{C}$ in $\mathrm{SP} 4$ (autumn), the average values in spring, summer and autumn were $10.80,16.81$ and $11.93^{\circ} \mathrm{C}$, respectively, whereas the average value with standard deviation for the three seasons has been $13.18 \pm 3.73^{\circ} \mathrm{C}$. The $\mathrm{pH}$ ranged from $6.9 \mathrm{in}$ SP1 (autumn) to 8.7 in SP1 (spring). The average values in spring, summer and autumn were $8.375,8.265$ and 7.296 , respectively, whereas the average value with standard deviation for the three seasons for $\mathrm{pH}$ was $7.98 \pm 0.55$. The concentrations of nitrate ranged from 0.0 .00 in 
Table.1. Results of the water analysis during the study period. The first row represents mean \pm SD and the second row represents the lowest and highest observed values

\begin{tabular}{|c|c|c|c|c|c|c|c|c|}
\hline Sites & \multirow{2}{*}{$\mathrm{S} 1$} & $\mathrm{~S} 2$ & $\mathrm{~S} 3$ & $\mathrm{~S} 4$ & $\mathrm{~S} 5$ & $\mathrm{~S} 6$ & $\mathrm{~S} 7$ & $\mathrm{~S} 8$ \\
Symbol & & & & & & & \\
\hline \multirow{2}{*}{$\mathrm{T}{ }^{\circ} \mathrm{C}$} & $9.16 \pm 0.70{ }^{\circ} \mathrm{C}$ & $12.5 \pm 1.35$ & $13.3 \pm 2.26$ & $14.3 \pm 5.71$ & $14.86 \pm 3.64$ & $10.08 \pm 3.50$ & $14.26 \pm 5.46$ & $13.93 \pm 5.56$ \\
& $8.5-9.9$ & $11.2-13.9$ & $11.4-15.8$ & $9.7-20.7$ & $12.1-19$ & $9.1-15.7$ & $9.9-20.4$ & $10-20.3$ \\
\hline \multirow{2}{*}{$\mathrm{pH}$} & $7.93 \pm 0.92$ & $7.95 \pm 0.75$ & $8.12 \pm 0.71$ & $7.8 \pm 0.61$ & $8.22 \pm 0.58$ & $7.70 \pm 0.35$ & $7.92 \pm 0.43$ & $8.15 \pm 0.44$ \\
& $6.9-8.7$ & $7.09-8.4$ & $7.31-8.65$ & $7.13-8.30$ & $7.55-8.61$ & $7.31-8.0$ & $7.42-8.2$ & $7.65-8.5$ \\
\hline \multirow{2}{*}{$\mathrm{EC}$} & $69.93 \pm 31.04$ & $135 \pm 20.81$ & $232.2 \pm 78.84$ & $596.3 \pm 169.0$ & $252.2 \pm 87.11$ & $553.6 \pm 180.9$ & $522.3 \pm 112.3$ & $384 \pm 93.1$ \\
& $41.4-103.0$ & $123.7-159.9$ & $145.7-300$ & $411.0-742.0$ & $155.7-325$ & $356-711$ & $400-621$ & $285-470$ \\
\hline \multirow{2}{*}{$\mathrm{TDS}$} & $35.16 \pm 15.86$ & $67.9 \pm 10.0$ & $116.3 \pm 39.3$ & $298.0 \pm 74.78$ & $126.8 \pm 42.3$ & $276.8 \pm 90.45$ & $261.3 \pm 56.4$ & $192.3 \pm 46.36$ \\
& $20.5-52.0$ & $62.0-79.5$ & $73.1-150$ & $205.0-371.0$ & $80-162$ & $178-355$ & $200-311$ & $143.0-235.0$ \\
\hline \multirow{2}{*}{$\mathrm{O}_{2}$} & $8.11 \pm 1.82$ & $8.75 \pm 1.62$ & $9.06 \pm 3.12$ & $6.88 \pm 1.67$ & $8.53 \pm 3.16$ & $5.43 \pm 3.11$ & $7.39 \pm 1.62$ & $7.96 \pm 1.79$ \\
& $6.7-10.2$ & $6.95-10.1$ & $6.67-12.6$ & $5.71-8.8$ & $6.05-12.1$ & $1.9-7.8$ & $5.5-8.6$ & $5.9-9.2$ \\
\hline \multirow{2}{*}{$\mathrm{COD}$} & $3.45 \pm 2.16$ & $7.93 \pm 6.87$ & $1.46 \pm 1.27$ & $33.9 \pm 14.46$ & $6.74 \pm 7.84$ & $41.8 \pm 9.69$ & $29.96 \pm 9.55$ & $22.43 \pm 17.5$ \\
& $2.6-4.3$ & $3.1-15.8$ & $0.0-2.3$ & $17.2-42.5$ & $2.13-15.8$ & $35.0-62.9$ & $19.4-38.0$ & $2.3-34.0$ \\
\hline \multirow{2}{*}{$\mathrm{BOD}$} & $1.10 \pm 1.02$ & $3.66 \pm 2.90$ & $0.5 \pm 0.5$ & $15.9 \pm 11.56$ & $5.48 \pm 5.76$ & $28.7 \pm 11.6$ & $15.16 \pm 7.08$ & $12.46 \pm 10.37$ \\
& $0.30-1.90$ & $1.7-7.0$ & $0.0-1.1$ & $3.1-25.16$ & $0.5-11.8$ & $16-38.8$ & $8.5-22.6$ & $1.0-21.2$ \\
\hline \multirow{2}{*}{$\mathrm{NO}_{3}{ }^{-}$} & $1.23 \pm 1.12$ & $0.53 \pm 0.66$ & $3.9 \pm 3.7$ & $4.43 \pm 3.26$ & $3.85 \pm 3.72$ & $0.76 \pm 1.15$ & $3.43 \pm 3.49$ & $9.56 \pm 9.25$ \\
& $0.0-2.2$ & $0.15-1.3$ & $0.13-7.60$ & $1.0-7.5$ & $0.16-7.6$ & $0.10-2.10$ & $0.5-7.3$ & $1.8-19.8$ \\
\hline \multirow{2}{*}{$\mathrm{NH}_{4}{ }^{+}$} & $000 \pm 000$ & $0.018 \pm 0.010$ & $0.016 \pm 0.010$ & $3.29 \pm 3.13$ & $1.25 \pm 0.27$ & $3.56 \pm 2.24$ & $1.90 \pm 0.41$ & $1.91 \pm 1.01$ \\
& $000-000$ & $0.017-0.018$ & $0.012-0.019$ & $1.15-6.9$ & $1.08-1.57$ & $1.36-5.84$ & $1.66-2.38$ & $1.21-3.07$ \\
\hline \multirow{2}{*}{$\mathrm{PO}_{4}{ }^{3-}$} & $0.023 \pm 0.023$ & $0.025 \pm 0.014$ & $0.036 \pm 0.021$ & $0.81 \pm 1.31$ & $0.033 \pm 0.015$ & $0.92 \pm 1.07$ & $0.86 \pm 1.27$ & $0.31 \pm 0.34$ \\
& $<0.02-0.023$ & $0.025-0.025$ & $0.036-0.036$ & $0.05-2.32$ & $0.024-0.050$ & $0.11-2.14$ & $0.06-2.33$ & $0.049-0.70$ \\
\hline \multirow{2}{*}{$\mathrm{SO}_{4}{ }^{2-}$} & $3.33 \pm 3.21$ & $4.0 \pm 1$ & $4.66 \pm 2.51$ & $12.66 \pm 2.88$ & $5.0 \pm 3.6$ & $16 \pm 9.84$ & $12.33 \pm 5.13$ & $10 \pm 2$ \\
\hline
\end{tabular}

$\mathrm{S} 1$ to $19.800 \mathrm{mg} / \mathrm{L}$ in $\mathrm{S} 8$. The variation of $\mathrm{EC}$ has been from $41.40 \mu \mathrm{S} / \mathrm{cm}$ in SP1 (spring) to $742.00 \mu \mathrm{S} / \mathrm{cm}$ in SP4 (summer). The average values in spring, summer and autumn were $239.813,414.913$ and $375.250 \mu \mathrm{S} / \mathrm{cm}$, respectively, whereas the average value with standard deviation for the three seasons for EC reached $343.33 \pm 212.31 \mu \mathrm{S} / \mathrm{cm}$. The values of TDS ranged from $20.50 \mathrm{mg} / \mathrm{L}$ in SP1 (spring) to $371.00 \mathrm{mg} / \mathrm{L}$ in $\mathrm{SP} 4$ (summer). The average values in spring, summer and autumn were $120.238,207.438$ and $187.875 \mathrm{mg} / \mathrm{L}$, respective$1 \mathrm{y}$, whereas the average value with standard deviation for the three seasons for TDS amounted to $171.85 \pm 106.04 \mathrm{mg} / \mathrm{L}$. The value of COD ranged from $00.00 \mathrm{mg} / \mathrm{L}$ in SP3 (summer) to $52.90 \mathrm{mg} / \mathrm{L}$ in SP6 (summer). The average values in spring, summer and autumn were 19.488, 12.329 and $23.150 \mathrm{mg} / \mathrm{L}$, respectively, whereas the average value with standard deviation for the three seasons for COD reached $18.32 \pm 17.21 \mathrm{mg} / \mathrm{L}$. The variation of $\mathrm{BOD}_{5}$ was from $00.00 \mathrm{mg} / \mathrm{L}$ in $\mathrm{SP} 3$ (summer) to $38.800 \mathrm{mg} / \mathrm{L}$ in SP6 (summer). The average values in spring, summer and autumn were $8.513,8.058$ and $14.450 \mathrm{mg} / \mathrm{L}$ respectively, whereas the average value with standard deviation for the three seasons for $\mathrm{BOD}_{5}$ amounted to $10.34 \pm 11.24 \mathrm{mg} / \mathrm{L}$. The value of $\mathrm{NO}_{3}^{-}$was from $00.00 \mathrm{mg} / \mathrm{L}$ in $\mathrm{SP} 1$ (spring) to 19.800 $\mathrm{mg} / \mathrm{L}$ in SP8 (summer). The average values in spring, summer and autumn were 1.205, 6.444 and $2.775 \mathrm{mg} / \mathrm{L}$ respectively, whereas the average value with standard deviation for the three seasons for $\mathrm{NO}_{3}{ }^{-}$reached $3.48 \pm 4.46 \mathrm{mg} / \mathrm{L}$. The variation of $\mathrm{NH}_{4}^{+}$was from $0.010 \mathrm{mg} / \mathrm{L}$ in several stations up to $6.900 \mathrm{mg} / \mathrm{L}$ in SP4 (spring). The average values in spring, summer and autumn were $2.477,0.815$ and $1.198 \mathrm{mg} / \mathrm{L}$ respectively, while the average value with standard deviation for the three seasons for $\mathrm{NH}_{4}^{+}$amounted to $1.50 \pm 1.82 \mathrm{mg} / \mathrm{L}$. The variation of $\mathrm{PO}_{4}{ }^{3-}$ was from $0.020 \mathrm{mg} / \mathrm{L}$ at several stations (in different season) up to $2.335 \mathrm{mg} / \mathrm{L}$ at SP7 (summer). The average values in spring, summer and autumn were $0.129,0.956$ and $0.047 \mathrm{mg} / \mathrm{L}$ respectively, while the average value with standard deviation for the three seasons for $\mathrm{PO}_{4}{ }^{3-}$ was $0.38 \pm 0.75$ $\mathrm{mg} / \mathrm{L}$. The sulphates of $\mathrm{SO}_{4}{ }^{2-}$ ranged from 1.000 $\mathrm{mg} / \mathrm{L}$ in SP1 (summer) and SP5 (summer) up to $27.000 \mathrm{mg} / \mathrm{L}$ in SP6 (autumn). The average values in spring, summer and autumn were 7.250, 6.625 and $11.625 \mathrm{mg} / \mathrm{L}$, respectively, while the average value with standard deviation for the three seasons for $\mathrm{SO}_{4}^{2-}$ was $8.50 \pm 6.00 \mathrm{mg} / \mathrm{L}$.

Table 2 shows that during the research on the Lepenci River basin, there are 139 identified species of diatoms belonging to 8 families; the Naviculaceae familiy has the highest abundance and distribution, whereas the species with highest abundance corresponds to Nitzschia dissipata 
Table 2. List of identified taxa in study river Lepenci basin.

\begin{tabular}{|c|c|c|c|c|c|c|c|c|c|}
\hline CODE & Taxa & S1 & $\mathrm{S} 2$ & S3 & S4 & S5 & S6 & S7 & S8 \\
\hline ADEG & Achnanthidium exiguum(Grunow) D. B. Czarnecki & & & & & & & + & \\
\hline ADGL & Achnanthidium gracillimum (Meister) Lange-Bertalot & + & & & & & & & \\
\hline ADMI & Achnanthidium minutissimum (Kützing) Czarnecki. & & & & & & & + & \\
\hline ADPY & Achnanthidium pyrenaicum (Hustedt) Kobayasi & & & & & & & + & \\
\hline ACOP & Amphora copulata (Kützing) Schoemann et Archibald & & & + & & & & & \\
\hline AOVA & Amphora ovalis (Kützing) Kützing & & & & & & + & + & \\
\hline APED & Amphora pediculus (Kützing) Grunow & + & & & & & & & \\
\hline AVEN & Amphora venetaKützing & & + & & & & & & \\
\hline $\mathrm{ASPH}$ & Anomoeoneis sphaerophora (Kützing) Pfitzer & & & & & & & + & \\
\hline BPAR & Bacillaria paradoxa Gmelin & + & & + & & + & & + & + \\
\hline CAMP & Caloneis amphisbaena (Bory) Cleve & & & & & & + & + & \\
\hline CBAC & Caloneis bacillum (Grunow) Cleve & & & & & & & + & \\
\hline CPED & Cocconeis pediculus Ehrenberg. & & + & + & & & + & + & \\
\hline CPEA & Cocconeis placentula var. euglypta (Ehrenberg) Cleve. & + & + & + & + & & & & + \\
\hline CPLM & Cocconeis placentula var. lineata (Ehrenberg) Cleve. & + & + & + & + & & + & + & + \\
\hline COPL & Cocconeis pseudolineata (Geitler) Lange-Bertalot. & + & & & + & + & & & \\
\hline CAMB & Craticula ambigua (Ehrenberg) D. G. Mann. & & & & + & + & + & + & + \\
\hline CRBU & Craticula buderi (Hustedt) Lange-Bertalot & & + & & & + & & + & \\
\hline CRCU & Craticula cuspidata (Kützing) D. G. Mann. & + & + & & + & + & & + & \\
\hline CCMP & Cymbella compacta Østrup. & + & & + & & & & & \\
\hline CCYM & Cymbella cymbiformis Agardh & & + & + & & & + & & \\
\hline CAEX & Cymbella excisa Kützing. & & & + & + & + & & & \\
\hline CLAN & Cymbella lanceolata (Ehrenberg) Kirchner. & + & + & + & & & & & \\
\hline CLBE & Cymbella lange-bertalotii Krammer & & + & + & & & + & & \\
\hline $\mathrm{CNCl}$ & Cymbella neocistula Krammer & + & + & & & & & & \\
\hline CTUM & Cymbella tumida (Brébisson) Van Heurck & + & + & + & + & + & + & & \\
\hline DELO & Diatoma elongatum (Lyngb. ) & & & & & & & + & \\
\hline DHQU & Diatoma hyemalis (Roth) Heiberg. & + & & & & + & & & + \\
\hline DMES & Diatoma mesodon (Ehrenberg) Kützing. & + & & & & & & & \\
\hline DMOF & Diatoma moniliformis Kützing. & & & & & & & & + \\
\hline DVUL & Diatoma vulgaris Bory. & & + & + & + & + & + & + & + \\
\hline DKRA & Diploneis krammeri Lange-Bertalot. & + & & & + & & & + & \\
\hline ENMI & Encyonema minutum (Hilse) D. G. Mann. & + & & + & + & + & & & + \\
\hline EPRO & Encyonema prostratum (Berkeley) Kützing. & + & + & + & & & & & \\
\hline ESLE & Encyonema silesiacum (Bleisch) D. G. Mann & & & + & & + & & & + \\
\hline EOMI & Eolimna minima (Hustedt)Lange-Bertalot & + & & & + & & + & + & + \\
\hline EGLA & Eunotia glacialis Meister. & & & & & + & & + & + \\
\hline EGRA & Eunotia gracilis(Eer. ) Rabh. & + & & & & & & & \\
\hline ELCA & Eunotia lunaris (Ehr) Grun. & + & & & & & & & \\
\hline FHEL & Fallacia helensis (Schulz) D. G. Mann. & & & & & & & + & \\
\hline FPYG & Fallacia pygmaea (Kützing) Stickle \& Mann & & + & & & & & & \\
\hline FBIC & Fragilaria bicapitata Mayer. & + & & & & & & + & \\
\hline FCCP & Fragilaria capucina var. capitellata (Kützing) Lange-Bertalot. & + & & & & & & & \\
\hline VCVA & Fragilaria capucina var. vaucheriae (Kützing) Lange-Bertalot. & & & & & & + & + & \\
\hline FSAX & Frustulia saxonica Rabenhorst & & & & + & & + & + & \\
\hline FVUL & Frustulia vulgaris (Thwaites) De Toni. & + & & & & & + & & \\
\hline KEDC & Geissleria decussis (Østrup) Lange-Bertalot \& Metzeltin & + & & & + & & + & & \\
\hline GAUG & Gomphonema augur Ehrenberg & & + & & & & & & \\
\hline GCAP & Gomphonema capitatum Ehrenberg. & + & & & & & & & + \\
\hline GCLA & Gomphonema clavatum Ehrenberg. & + & + & + & & & + & + & + \\
\hline GEXL & Gomphonema exilissimum (Grunow) Lange-Bertalot \& Reichardt. & & & + & + & & & & \\
\hline GGRA & Gomphonema gracile Ehrenberg & + & & & & + & & & \\
\hline
\end{tabular}


Table 2. cont.

\begin{tabular}{|c|c|c|c|c|c|c|c|c|c|}
\hline CODE & Taxa & S1 & S2 & S3 & S4 & S5 & S6 & S7 & S8 \\
\hline GINT & Gomphonema intricatum Kützing & & & & & & + & & \\
\hline GITA & Gomphonema italicum Kützing & & & & & + & & & \\
\hline GMIC & Gomphonema micropus Kützing. & + & & & + & + & + & + & \\
\hline GMIN & Gomphonema minutum (C. Agardh) C. Agardh. & & + & + & & + & & + & \\
\hline GOLI & Gomphonema olivaceum (Hornemann) Brébisson. & & + & + & & + & + & & \\
\hline GPAR & Gomphonema parvulum (Kützing) Kützing, & & & & + & & & & \\
\hline GPUM & Gomphonema pumilum (Grunow) Reichardt \& Lange-Bertalot & + & & + & & & & & \\
\hline GROS & Gomphonema rosenstockianum Lange-Bertalot \&Reichardt & + & + & & + & & & & \\
\hline GSCL & Gomphonema subclavatum (Grunow) Grunow. & + & + & + & & + & + & + & \\
\hline GRSI & Grunowia sinuata Thwaites & & + & & & & & & \\
\hline HARC & Hannaea arcus (Ehrenberg) Patrick & + & + & & & & & & \\
\hline HAHS & Hantzschia amphioxys (Ehrenberg) Grunow. & & & & + & & & & \\
\hline HHUN & $\begin{array}{l}\text { Hippodonta hungarica (Grunow) Lange-Bertalot Meltzeltin \& } \\
\text { Witkowski }\end{array}$ & & & + & & & & & \\
\hline LGOE & Luticola goeppertiana (Bleish) D. G. Mann & + & & + & + & & + & & \\
\hline MVAR & Melosira varians Agardh. & + & + & & + & & & & \\
\hline $\mathrm{MCIR}$ & Meridion circulare (Greville) C. A. Agardh & + & + & & & & + & & \\
\hline NANT & Navicula antonii Lange-Bertalot. & & + & + & + & & + & & \\
\hline NCPR & Navicula capitatoradiata Germain. & + & + & & & & & + & \\
\hline NAOT & Navicula cf. antonii Lange-Bertalot. & & & & & & & + & \\
\hline NCBA & Navicula confervacea Kützing. & & & & & & & + & \\
\hline NCTE & Navicula cryptotenella Lange-Bertalot. & & + & + & + & + & + & & + \\
\hline NCUS & Navicula cuspidata Kützing & & & & & & & + & \\
\hline NERI & Navicula erifuga Lange-Bertalot. & & + & + & & & + & & + \\
\hline NGRE & Navicula gregaria Donkin & & + & & + & & & + & + \\
\hline $\mathrm{NHAL}$ & Navicula halophila (Grun. ) & & & & & & & + & \\
\hline NHLV & Navicula helvatica Brun. & & & & + & & & + & \\
\hline $\mathrm{NHIN}$ & Navicula hintzii Lange-Bertalot. & + & + & & + & + & + & + & + \\
\hline NLAN & Navicula lanceolata (Agardh) Ehrenberg & + & + & + & + & & + & & \\
\hline NOBL & Navicula oblonga Kützing. & & & & & & & & + \\
\hline NOLI & Navicula oligotraphenta Lange-Bertalot \& Hofmann & & + & & & & & & \\
\hline NPEP & Navicula perpusilla Grun. & & & & & & & + & \\
\hline NPLT & Navicula placenta Ehr. & & & & & & + & & \\
\hline NRAD & Navicula radiosa Kützing & + & + & & + & & + & + & + \\
\hline $\mathrm{NRCH}$ & Navicula reichardtiana Lange-Bertalot & & & & & & & + & \\
\hline NRHY & Navicula rhynchocephala Kützing & + & + & & & & & + & \\
\hline NROS & Navicula rostellata Kützing & & & & + & & + & & + \\
\hline NSPD & Navicula splendicula Van Landingham & & & + & & & & + & + \\
\hline NSRH & Navicula subrhynchocephala Hustedt & & & & & & & & + \\
\hline NTPT & Navicula tripunctata Bory & & + & & + & & + & & \\
\hline NVEN & Navicula veneta Kützing & + & & & & & & & \\
\hline NVIR & Navicula viridula (Kützing) Ehrenberg & + & + & + & + & + & + & + & + \\
\hline $\mathrm{NACl}$ & Nitzschia acicularis (Kützing) W. Smith & & & & + & + & & & \\
\hline NDIS & Nitzschia dissipata (Kützing) Grunow & & & + & + & + & + & + & + \\
\hline NFON & Nitzschia fonticola Grunow & & & & & + & & & \\
\hline NIFR & Nitzschia frustulum (Kützing) Grunow & + & + & + & & & & + & + \\
\hline NGDF & Nitzschia gracilis Hantzsch & & & + & + & & & & \\
\hline NLIN & Nitzschia linearis (Agardh) W. Smith & & + & & & + & & + & \\
\hline NOBT & Nitzschia obtusa W. Sm. & & & & & & & + & + \\
\hline NPLA & Nitzschia palea (Kützing) W. Smith & + & & + & + & & & & + \\
\hline NREC & Nitzschia recta Hantzsch & & & & + & & + & & \\
\hline NSIG & Nitzschia sigma (Kützing) W. Smith & & + & + & & & & & + \\
\hline NSIO & Nitzschia sigmoidea (Nitzsch) W. Smith & + & + & + & & & & & + \\
\hline
\end{tabular}


Table 2. cont.

\begin{tabular}{|c|c|c|c|c|c|c|c|c|c|}
\hline CODE & Taxa & S1 & S2 & S3 & S4 & S5 & S6 & S7 & S8 \\
\hline NSOC & Nitzschia sociabilis Hustedt & & + & + & + & + & + & + & \\
\hline NZSB & Nitzschia spectabilis (Ehr) Ralfs. & + & & + & & & & & \\
\hline NVAG & Nitzschia umbonata (Ehrenberg) Lange-Bertalot & & & & & & & + & \\
\hline NVAG & Nitzschia vermicularis (Kützing) Grunow & + & & & & & + & & \\
\hline PBOR & Pinnularia borealis Ehrenberg & & & + & & & & & \\
\hline PMBR & Pinnularia microstauron (Kützing) Rabenhorst & & & & & & & & + \\
\hline PNEX & Placoneis neoexigua Lange-Bertalot \& Miho & & & & & & & + & \\
\hline PTLA & Planothidium lanceolatum (Brébisson) Lange-Bertalot & + & & & & & + & & \\
\hline RUNI & Reimeria uniseriata Sala, Guerrero \& Ferrario. & & & & & & & & + \\
\hline RABB & Rhoicosphenia abbreviata (Agardh) Lange-Bertalot & + & + & & + & + & + & + & + \\
\hline RGIB & Rhopalodia gibba (Ehrenberg) O. Müller & + & + & & & & & & \\
\hline SPUB & Sellaphora pupula (Kützing) Mereschowsky. & + & & & & & & & \\
\hline SREC & Sellaphora rectangularis (Gregory) Lange-Bertalot \& Metzeltin & & & & & & + & & \\
\hline SPIN & Staurosirella pinnata (Ehrenberg) D. M. Williams \& F. E. Round & + & + & & & & & & \\
\hline SBBI & Surirella biseriata Brébisson & & & & & & & + & \\
\hline SBRE & Surirella brebissonii Krammer \& Lange-Bertalot & & & + & & + & & & \\
\hline SBKU & Surirella brebissonii var. kuetzingii Krammer \& Lange-Bertalot & & & & + & & + & & + \\
\hline SUCA & Surirella capronii Breb. & & & & & + & & & \\
\hline SHEL & Surirella helvetica Brun. & & & & + & & & & \\
\hline SLBK & Surirella linearis W. Sm. & & & & & & & & + \\
\hline SUMI & Surirella minuta Brébisson & & + & & & & & & \\
\hline SOVI & Surirella ovalis Brébisson & & & & + & & & & \\
\hline SOVA & Surirella ovataKutz & & & & & + & & & \\
\hline SOSA & Surirella ovata var. salina (W. Sm) Hust. & & & & & & & & + \\
\hline SURO & Surirella robusta Ehr. & & & & & + & & & + \\
\hline SULN & Synedra ulna (Nitszch) Ehr. & & + & & & & + & + & \\
\hline TBIN & Tabellaria binalis (Ehr. ) Grun. & + & & & & & & & \\
\hline TBLO & Tabellaria flocculosa (Roth) Kützing. & + & & & & & & & \\
\hline TBSP & Tabularia spec & & & & & & + & & \\
\hline TWEI & Thalassiosira weissflogii (Grunow) Fryxell \& Hasle & & & & & & & & + \\
\hline TAPI & Tryblionella apiculata Gregory & & + & + & + & & & + & \\
\hline TCAL & Tryblionella calida (Grunow) D. G. Mann. & + & & & & & & & + \\
\hline UACU & Ulnaria acus (Kützing) Aboal & + & + & + & & & & & \\
\hline UBIC & Ulnaria biceps (Kützing) Compère & + & & + & & + & & & \\
\hline UULN & Ulnaria ulna (Kützing) Compère. & + & & & & & + & & \\
\hline
\end{tabular}

(Kützing) Grunow (4.69\%), Rhoicosphenia abbreviata (Agardh) Lange-Bertalot (3.21\%), Diatoma vulgaris Bory. (3.13\%), Cocconeis placentula var. lineata (Ehrenberg) Cleve (2.62\%), Navicula viridula (Kützing) Ehrenberg (2.46\%), Navicula hintzii Lange-Bertalot(2.36\%),Nitzschia frustulum (Kützing) Grunow (2.07\%), Navicula erifuga Lange-Bertalot (2.04\%), Hannaea arcus (Ehrenberg) Patrick (1.88\%), Navicula cryptotenella Lange-Bertalot (1.85\%), Gomphonema clavatum Ehrenberg (1.78\%), Navicula gregaria Donkin $(1.75 \%)$ dhe Navicula capitatoradiata Germain (1.75\%) etc. The largest distribution species during the course of the Lepenci River Basin were Navicula viridula (Kützing) Ehrenberg,
Navicula hintzii Lange-Bertalot, Rhoicosphenia abbreviata (Agardh) Lange-Bertalot, Diatoma vulgaris Bory, Cocconeis placentula var. lineata (Ehrenberg) Cleve.

In order to determine the ecological as well as trophic status of waters, thirteen indices were employed for Diatom survey, as shown in Table 3.

In SP1-Prevallë station, based on the indices calculated using the OMNIDIA software, it can be considered that the water quality is good and belongs to the second class while its trophic status is Oligo-Mesotroph. The analyzed indices were: IBD, IPS, IDG, SLA, IDSE, EPID, CEE, WAT, TDI and SHE, the same were used in all eight sampling plot analyses. Interestingly, based on 


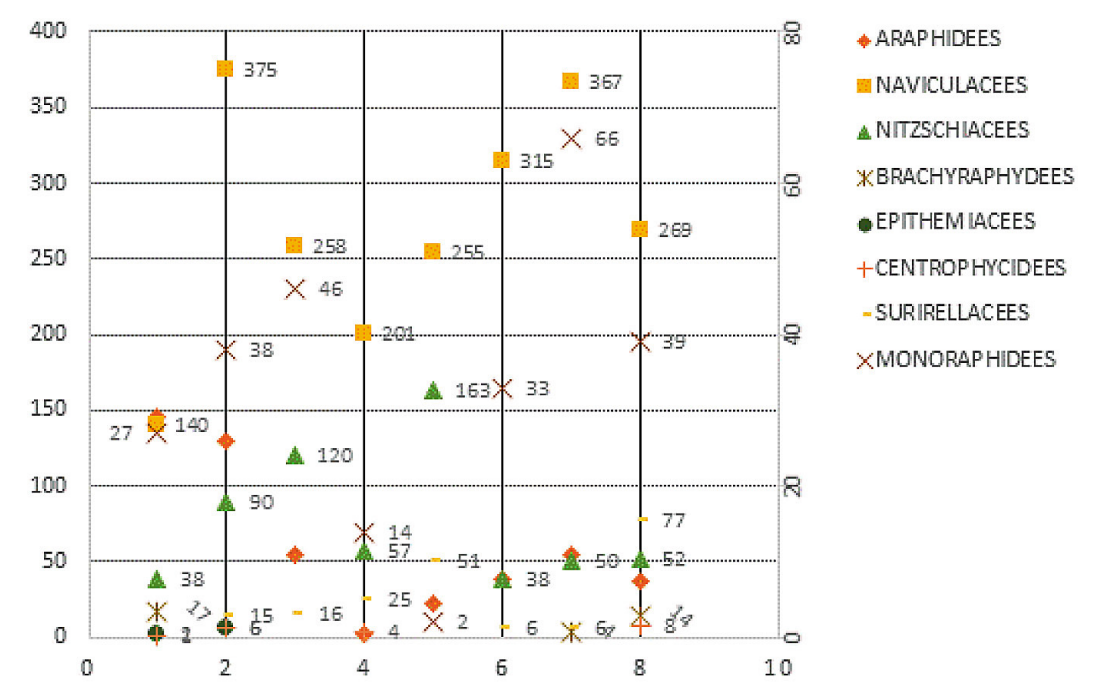

Figure 2. Distribution of taxa group based on the number of individuals
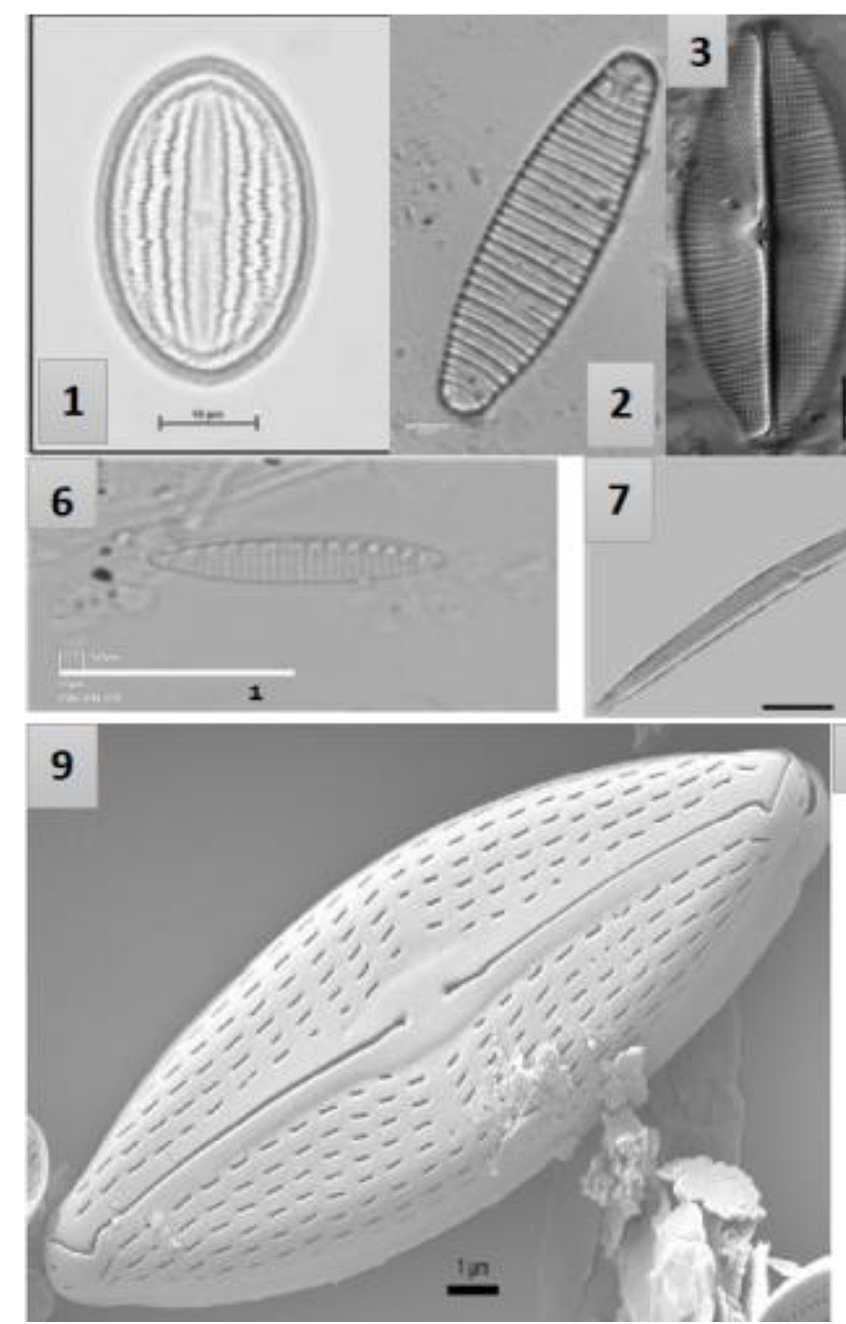

2
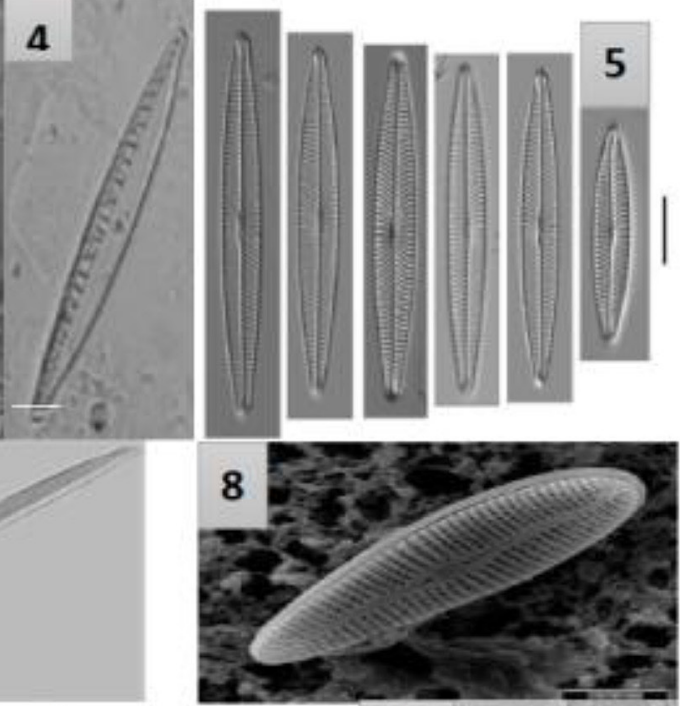

10

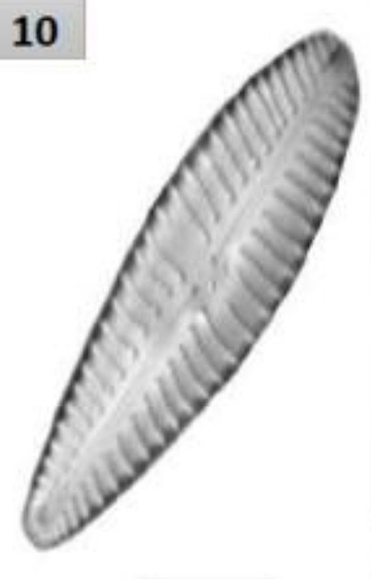

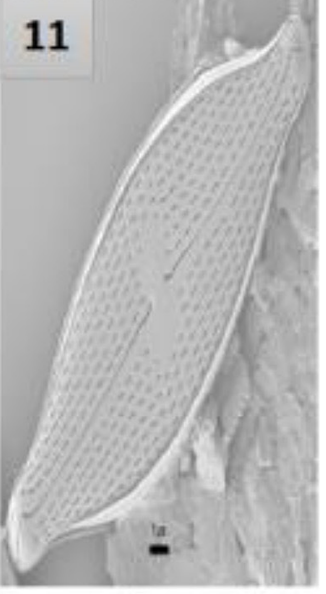

Figure 3. 1. Cocconeis placentula var. lineata (Ehrenberg) Cleve, 2. Diatoma vulgaris Bory, 3. Navicula viridula (Kützing) Ehrenberg, 4. Nitzschia dissipata (Kützing) Grunow, 5. Navicula lanceolata (Agardh) Ehrenberg, 6. Nitzschia frustulum (Kützing) Grunow, 7. Hannaea arcus (Ehrenberg) Patrick, 8. Rhoicosphenia abbreviata (Agardh) Lange-Bertalot, 9. Navicula cryptotenella Lange-Bertalot, 10. Gomphonema clavatum Ehrenberg, 11. Navicula gregaria Donkin 
Table 3. Classes limit values for diatom indices

\begin{tabular}{|c|c|c|c|}
\hline $\begin{array}{c}\text { Water quality } \\
\text { class }\end{array}$ & $\begin{array}{c}\text { Ecological } \\
\text { status }\end{array}$ & $\begin{array}{c}\text { IPS, CEE, IBD, IDG, DESCY, SLA, IDSE, IDAP, } \\
\text { EPID, WAT, TDI, IDP, SHE }\end{array}$ & Trophic status \\
\hline I & High & $17-20$ & Oligotrophic \\
\hline II & Good & $13-16$ & Oligo-mesotrophic \\
\hline III & Moderate & $9-12$ & Mesotrophic \\
\hline IV & Poor & $5-8$ & Eutrophic \\
\hline V & Bad & $1-4$ & Hypertrophic \\
\hline
\end{tabular}

the Descy index, the water quality is high which means that the water quality belongs to the first class (I) and trophic level is Oligotrophic. On the other hand, according to the IDAP \& IDP indices, the water quality is moderate, and belongs to the third class (III) with Mesotrophic level.

In SP2-Jezerc station, according to the values of the IBD, Descy, IDSE, CEE and WAT indices, the quality of water is good and belongs to the second class (II), and the trophic status is Oligo-Mesotroph. Additionally, according to the IPS, IDG, SLA, ISAP, EPID, TDI, IDP and SHE indices, the water quality is moderate, and belongs to the third class (III) and trophic level is mesotrophic.

According to the values of the IBD, IDG, IDSE, IDAP, CEE, WAT, SHE indices, the quality of water is good and belongs to the second class (II), whereas the trophic status is Oligo-mesotrophic. In turn, based on the Descy index, the water quality is high which means that the water quality belongs to the first class (I) and trophic level is Oligotroph. According to the IPS, SLA, EPID, IDP indices, the water quality is moderate, and belongs to the third class (III) whereas the trophic level is mesotrophic. On the basis of the TDI index, the water is of poor quality, belongs to the fourth class (IV) and trophic level is Meso-eutrophic.

The obtained values for the diatom indices on the fourth monitoring station - SP4-Runjevë (Table 4) - indicate good water status and, which belongs to the second class (II) and the oligoMesotroph level. In turn, IPS, IDG, SLA, IDSE, IDAP, EPID, CEE, WAT, IDP and SHE indicate moderate status and the third class (III) as well as mesotrophic level. On the basis of the TDI index, the water is of poor quality, i.e. to the fourth classes (IV) and the trophic level is Meso-eutrophic.

For the fifth monitoring station, Nikë (Table 4), most of the diatom indices show moderate water status (IPS, IDG, SLA, IDSE, EPID, CEE, IDP) and its quality belongs to the third class (III) as well as Mesotrophic level. IBD, DESCY, IDAP, WAT and SHE indicate good status and second class (II) quality, with the trophic status being Oligo-mesotrophic while TID (poor status) belongs to the fourth class (IV), and Meso-eutrophic level.

Most of the scores for the diatom indices for the sixth monitoring station - Gërlicë - belong

Table 4. The values of diatom indices IBD, IPS, IDG, Descy, Sla, IDSE, IDAP, EPID, CEE, WAT, TDI, IDP, SHE, calculated for individual sites in the Lepenci River basin stream

\begin{tabular}{|c|c|c|c|c|c|c|c|c|}
\hline Indices & Sites & S2 & S3 & S4 & S5 & S6 & S7 & S8 \\
\hline IBD & 16.7 & 13.9 & 13.3 & 13.3 & 13.9 & 13.5 & 12.5 & 11.9 \\
\hline IPS & 14.8 & 12.5 & 12.2 & 12.7 & 11.9 & 13.1 & 11.4 & 10.8 \\
\hline IDG & 13.8 & 12.6 & 13.3 & 11.7 & 12.3 & 12.1 & 11.9 & 12.1 \\
\hline Descy & 17.1 & 16.9 & 17.2 & 15.2 & 15.9 & 16.4 & 16.6 & 16 \\
\hline Sla & 14.5 & 12 & 12.2 & 11.1 & 11.9 & 11.9 & 11.6 & 11.8 \\
\hline IDSE & 14.5 & 13.1 & 13.3 & 12.1 & 12.6 & 13.9 & 12.9 & 13 \\
\hline IDAP & 10.4 & 10.7 & 13.1 & 12.8 & 13 & 12.8 & 11.8 & 12.7 \\
\hline EPID & 14.4 & 11.3 & 11.4 & 9.9 & 10.7 & 10.6 & 10.9 & 10.1 \\
\hline CEE & 15.2 & 14.3 & 14.8 & 11.2 & 12.5 & 13.3 & 13.2 & 11.8 \\
\hline WAT & 13.7 & 13.7 & 14.7 & 12.2 & 13.6 & 11 & 12.2 & 12.3 \\
\hline TDI & 14.4 & 9.3 & 5.9 & 5.3 & 5.5 & 7.9 & 7.2 & 9.4 \\
\hline IDP & 12 & 11.4 & 12.2 & 9.5 & 11.8 & 12.2 & 11.8 & 11.8 \\
\hline SHE & 13 & 12.1 & 14.1 & 12.1 & 14 & 13.1 & 13.1 & 12.8 \\
\hline
\end{tabular}


to the good or the lower limit of moderate status (table 4). The values obtained for IBD, IPS, DESCY, IDSE and SHE show that the quality of water is good and it belongs to the second class (II), with the Oligo-mesotroph status, while for IDG, SLA, IDAP, EPID, CEE, WAT, ISD show moderate status and the third class (III) as well as mesotrophic level; in turn, TID shows poor status and belongs to the four classes (IV) while the trophic level is Meso-eutrophic.

Most of the scores for the diatom indices for the seventh monitoring station - Kaçanik - belong to moderate status (Table 4). The values obtained for IBD, IPS, IDG, SLA, IDSE, IDAP, EPID, WAT, IDP are moderate and belong to the third class (III), the trophic level is mesotrophic; TID shows poor status and belongs to the fourth class (IV). The trophic level is Meso-eutrophic. In turn, DESCY,SHE have good status and belong to the second class (II), and the trophic status is Oligo-mesotrophic.

For the eighth monitoring station Hani i Elezit, most of the diatom indices show moderate status (IBD, IPS, IDG, SLA, IDAP, EPID, CEE, WAT, TDI, IDP, SHE) and belong to the third class (III) as well as Mesotrophic level (Table 4). On the other hand, DESCY and IDAP indices show it to have good status and the water quality belongs to the second class (II), while the trophic status is Oligo-mesotrophic. This study is the first attempt to uncover the taxonomic composition and distribution of diatoms in the Lepenci River basin. Nearly 139 taxa, belonging to 43 genera, were recorded (Table 2). The composition of the diatoms assemblage changed from site to site and different monitoring stations. At the upper sites source area (S1-S3), in S1, the dominant species were Hannaea arcus (Ehrenberg) Patrick 8.6\%, Diodoma mesodon (Ehrenberg) Kützing 8.4\%, Ulnaria ulna (Kützing) Compere 5.9\%, Ulnaria biceps (Kützing) Compère 5.4\%, Diatoma hyemalis (Roth.) Heiberg 4.9\%. In S2, the dominant species included Diatoma vulgaris Bory 6.8\%, Nitzschia frustulum (Kützing) Grunow 6.2\%, Hannaea arcus (Ehrenberg) Patrick 5.9\%, Cymbella tumida (Brébisson) Van Heurck 5.3\% dhe Navicula gregaria Donkin 4.8\%, and at S3 the monitoring station, the dominant species were Nitzschia dissipata (Kützing) Grunow 11.1\%, Cymbella tumida (Brébisson) Van Heurck 8.7\%, Diatoma vulgaris

Table 5. Calculation of statistical results with ECO pack by number of species

\begin{tabular}{|c|c|c|c|c|c|c|c|c|}
\hline Symbol Sites & Prevallë & Jezerc & Brod & Runjevë & Nikë & Gërlicë & Kaçanik & Hani i Elezit \\
\hline$S$ & 57 & 48 & 42 & 41 & 32 & 42 & 51 & 38 \\
\hline $\mathrm{N}$ & 373 & 660 & 495 & 306 & 474 & 430 & 529 & 507 \\
\hline$S_{E}$ & 0 & 0 & 1 & 0 & 1 & 0 & 0 & 0 \\
\hline$S_{D}$ & 4 & 4 & 2 & 5 & 3 & 1 & 3 & 5 \\
\hline$S_{S} d$ & 12 & 15 & 18 & 13 & 16 & 21 & 15 & 15 \\
\hline$S_{R}$ & 14 & 15 & 11 & 13 & 10 & 13 & 26 & 14 \\
\hline$S_{S} r$ & 27 & 14 & 10 & 10 & 2 & 7 & 7 & 4 \\
\hline $\mathrm{N}_{\mathrm{E}}$ & 0 & 0 & 55 & 0 & 69 & 0 & 0 & 0 \\
\hline $\mathrm{N}_{\mathrm{D}}$ & 105 & 160 & 79 & 88 & 92 & 28 & 89 & 156 \\
\hline $\mathrm{N}_{\mathrm{S}} \mathrm{d}$ & 142 & 294 & 256 & 127 & 234 & 297 & 227 & 236 \\
\hline $\mathrm{N}_{\mathrm{R}}$ & 71 & 146 & 71 & 68 & 73 & 85 & 192 & 103 \\
\hline$N_{S} r$ & 55 & 60 & 34 & 23 & 6 & 20 & 21 & 12 \\
\hline$F_{1}$ & 4 & 0 & 0 & 2 & 0 & 0 & 1 & 0 \\
\hline $\mathrm{F}_{2}$ & 18 & 2 & 1 & 3 & 1 & 3 & 0 & 1 \\
\hline $\mathrm{F}_{3}$ & 5 & 4 & 4 & 5 & 0 & 2 & 4 & 2 \\
\hline $\mathrm{H}^{\prime}$ & 5.219405 & 5.209322 & 4.951315 & 5.049589 & 4.641079 & 5.143133 & 5.406122 & 4.95428 \\
\hline $\mathrm{E}$ & 0.894823 & 0.932741 & 0.918216 & 0.942518 & 0.928216 & 0.953789 & 0.953053 & 0.944045 \\
\hline$E^{\prime}$ & 0.858996 & 0.92205 & 0.902788 & 0.924932 & 0.91706 & 0.943718 & 0.94319 & 0.934611 \\
\hline D & 0.037109 & 0.033012 & 0.043159 & 0.03535 & 0.052573 & 0.032212 & 0.027762 & 0.037919 \\
\hline N2 & 26.94732 & 30.29207 & 23.17021 & 28.28882 & 19.021 & 31.04433 & 36.02021 & 26.37211 \\
\hline $\mathrm{D}_{\mathrm{Ma}}$ & 9.456938 & 7.239412 & 6.608045 & 6.988627 & 5.031481 & 6.761453 & 7.973225 & 5.940425 \\
\hline $\mathrm{D}_{\mathrm{Me}}$ & 2.951348 & 1.868397 & 1.88776 & 2.343814 & 1.469809 & 2.02542 & 2.217391 & 1.687639 \\
\hline $\mathrm{S}_{\text {Chao1 }}$ & 57.44444 & 48 & 42 & 41.66667 & 32 & 42 & NA & 38 \\
\hline $\operatorname{Var}\left(\mathrm{S}_{\text {Chao1) }}\right.$ & 0.652949 & 0 & 0 & 1.703704 & 0 & 0 & NA & 0 \\
\hline
\end{tabular}


Bory $7.3 \%$, Navicula erifuga Lange-Bertalot in Krammer \& Lange-Bertalot 4.4\%, Cymbella excisa Kützing 3.6\%. Further downstream (S4 and S8), in S4, the dominant species were Nitzschia dissipata (Kützing) Grunow 6.9\%, Navicula tripunctata (O. F. Müller) Bory 6.3\%, Navicula viridula (Kützing) Ehrenberg 5.3\%, Navicula radiosa Kützing 5.3\%, Gomphonema parvulum (Kützing) Kützing 5.3\%; in the S5 monitoring station, the dominant species were Nitzschia dissipata (Kützing) Grunow ssp. dissipata 14.6\%, Cymbella tumida (Brebisson) Van Heurck 7.2\%, Craticula cuspidata (Kützing) Mann 6.1\%, Surirella brebissonii Krammer \& Lange-Bertalot $6.1 \%$, Gomphonema micropus Kützing 4.4\%, in S6, the dominant species were Frustulia saxonica Rabenhorst $6.5 \%$, Navicula placenta Ehrenberg 4.9\%, Eolimna minima (Grunow) Lange-Bertalot in Moser \& al. 4.7\%, Craticula ambigua (Ehrenberg) Mann 4.4\%, Navicula lanceolata (Agardh) Ehrenberg 4.4\%, in S7 the dominant species were Navicula hintzii Lange-Bertalot $5.7 \%$, Navicula capitatoradiata Germain 5.7\%, Rhoicosphenia abbreviata (C. Agardh) LangeBertalot $4.9 \%$, Caloneis amphisbaena (Bory) Cleve 3.6\%, Cocconeis placentula var. lineata (Ehr.)Van Heurck f. anormale 3.5\% and in the S8 monitoring station the dominant species were Surirella brebissonii var. kuetzingii Krammer et Lange-Bertalot 7.9\%, Rhoicosphenia abbreviata (C. Agardh) Lange-Bertalot 6.7\%, Surirella linearis W. Smith var. baikalensis Skvortzow $6.5 \%$, Navicula rostellata Kützing $5.2 \%$, Craticula ambigua (Ehrenberg) Mann 5.2\%.

Referring to the data in Table 2 it was noticed that in the Lepenci River Basin, the largest number of Eudominant (SE) taxa was observed in the S3_Brod and S5_Nikë stations. The largest number of subdominant taxa (Ssd) in the Lepenci river basin was found in the S5 and S7 stations, while the lowest value - at the S6 station. The largest number of resident species (R) belongs to the S7_Nikë station 27, while the lowest number of resident species is at station S5_Nikë 10

The largest number of taxa with Sub-Resident (Ssr) frequency was found in the S1_Prevallë station with 27 taxa (families), and the lowest number in the S5_Nikë station with 2 taxa. The highest eudominant species (NE) abundance was observed at S5_Nikë 69 and S3 Brod 55. The largest dominant abundance (ND) was presented at S2_Jezerc (160) station while the lowest value was at S6_Gërlicë station (28). The abundance of resident species (NR) was the highest at the S7_Kaçanik station - 192, while the lowest was in the S4_Runjevë station -68 . The abundance of the sub-resident species (Nsr) as the highest at the S2_Jezerc station (60) while the lowest was at S5_Nikë station (6). The largest number of Sigletons (F1) and Doubletons (F2) was at the S1_Prevallë station. The largest number of Tripluses (F3) is displayed at the S1_Prevallë and S4_Runjevë stations.

Species richness estimator (Schao1) had the highest value at the S1_Prevallë station. Diversity index (Shannon-Wienner) and evenness index of epipelic diatom in river basin Lepenci are relatively high. Diversity index ranged from 4.64 up to 5.40 , while the evenness index values - from 0.85 to 0.95 , Margalef index 5.03 up to 9.45 and Menhinick index from 1.46 to 2.95 (Table 5). High diversity index reflects the stable ecosystem of Lepenci river basin downstream based on epipelic diatom community. Evenness index of epipelic diatom in Lepenci river basin downstream indicates the quite even of species distribution on these downstream rivers [Odum, 1993].

Table 6 shows that the greatest similarities in the composition of diatomic types were exhibited at between S2_Jezerc station with S3-Brod station, and S4_Runjevë and S6_Gërlicë station where Jacardi index is 0.36 or $36 \%$, which implies that these localities have $36 \%$ of common types. The greatest differences were shown

Table. 6. Similarity in diatoms species composition between sampling sites (Jaccard 's index)

\begin{tabular}{|c|c|c|c|c|c|c|c|}
\hline Sites & Jezerc & Brod & Runjevë & Nikë & Gërlicë & Kaçanik & Hani i Elezit \\
\hline Prevallë & 0.3125 & 0.253165 & 0.240506 & 0.171053 & 0.222222 & 0.173913 & 0.202532 \\
\hline Jezerc & & 0.363636 & 0.253521 & 0.19403 & 0.304348 & 0.253165 & 0.194444 \\
\hline Brod & & & 0.257576 & 0.254237 & 0.253731 & 0.1625 & 0.25 \\
\hline Runjevë & & & & 0.258621 & 0.360656 & 0.226667 & 0.253968 \\
\hline Nikë & & & & & 0.193548 & 0.220588 & 0.22807 \\
\hline Gërlicë & & & & & & 0.256757 & 0.212121 \\
\hline Kaqanik & & & & & & & 0.219178 \\
\hline
\end{tabular}


Table. 7. Diatom Sorensen similarity index in river Lepenci basin

\begin{tabular}{|c|c|c|c|c|c|c|c|}
\hline Sites & Jezerc & Brod & Runjevë & Nikë & Gërlicë & Kaçanik & Hani i Elezit \\
\hline Prevallë & 0.47619 & 0.40404 & 0.387755 & 0.292135 & 0.363636 & 0.296296 & 0.336842 \\
\hline Jezerc & & 0.533333 & 0.404494 & 0.325 & 0.466667 & 0.40404 & 0.325581 \\
\hline Brod & & & 0.409639 & 0.405405 & 0.404762 & 0.27957 & 0.4 \\
\hline Runjevë & & & & 0.410959 & 0.53012 & 0.369565 & 0.405063 \\
\hline Nikë & & & & & 0.324324 & 0.361446 & 0.371429 \\
\hline Gërlicë & & & & & & 0.408602 & 0.35 \\
\hline Kaqanik & & & & & & & 0.359551 \\
\hline
\end{tabular}

Table. 8. Pearson correlation coefficients between measured water quality variables and diatom indices

\begin{tabular}{|c|c|c|c|c|c|c|c|c|c|c|}
\hline $\begin{array}{l}\text { Indices } \\
\text { Symbol }\end{array}$ & $\mathrm{H}^{\prime}$ & E & E_A & D & N2 & $\mathrm{D}_{\mathrm{Ma}}$ & $\mathrm{D}_{\mathrm{Me}}$ & IBD & IPS & TDI \\
\hline $\mathrm{T},{ }^{\circ} \mathrm{C}$ & -.412 & .417 & .492 & .304 & -.208 & -.638 & -.621 & -.684 & $-.824^{*}$ & -.654 \\
\hline $\mathrm{pH}$ & -.651 & -.329 & -.192 & $.742^{*}$ & -.703 & -.500 & -.559 & -.160 & -.485 & -.336 \\
\hline EC & .149 & $.843^{* *}$ & $.759^{*}$ & -.406 & .450 & -.227 & -.083 & -.636 & -.372 & -.328 \\
\hline TDS & .148 & $.843^{* *}$ & $.760^{*}$ & -.405 & .449 & -.228 & -.085 & -.637 & -.374 & -.329 \\
\hline $\mathrm{O}_{2}$ & -.312 & -.602 & -.478 & .512 & -.515 & -.085 & -.228 & .154 & -.156 & -.072 \\
\hline COD & .324 & $.830^{*}$ & $.723^{*}$ & -.586 & .607 & -.058 & .048 & -.486 & -.188 & -.090 \\
\hline BOD & .229 & $.809^{*}$ & $.721^{*}$ & -.488 & .515 & -.145 & -.048 & -.433 & -.150 & -.157 \\
\hline $\mathrm{NO}_{3}^{-}$ & -.403 & .241 & .267 & .241 & -.268 & -.481 & -.392 & -.668 & -.702 & -.170 \\
\hline $\mathrm{NH}_{4}^{+}$ & .023 & $.768^{*}$ & .674 & -.305 & .326 & -.264 & -.066 & -.458 & -.198 & -.178 \\
\hline $\mathrm{PO}_{4}^{3-}$ & .429 & $.777^{\star}$ & .660 & -.629 & .673 & .069 & .165 & -.444 & -.146 & -.127 \\
\hline $\mathrm{SO}_{4}^{2-}$ & .273 & $.835^{* *}$ & $.737^{*}$ & -.532 & .557 & -.113 & -.003 & -.547 & -.246 & -.185 \\
\hline
\end{tabular}

* Correlation is significant at the 0.05 level (2-tailed).

** Correlation is significant at the 0.01 level (2-tailed).

between S3_Brod station and S7_Kaçanik station where Jakard's index is 0.17 or $17 \%$.

This index is expressed in \%, where the highest percentage also shows the highest similarity in the composition of two samples. Table 7 shows that the greatest similarity was obtained between the S2_Jezerc and S3_Brod stations, which have $53 \%$ of the types of common diatoms. The S3_Brod and S7_Kaçanik stations showed a similarity value of less than $27 \%$.

Table 8 shows the correlations between the physical-chemical parameters and indices. The authors found that $\mathrm{E}$ index is significantly and strongly correlated with EC, TDS COD and BOD $, \mathrm{NH}_{4}^{+}, \mathrm{PO}_{4}^{3-}, \mathrm{SO}_{4}{ }^{2-}$ parameters $(\mathrm{p}<0.05$ and $\mathrm{p}<0.01)$. The E_A index is significantly and strongly correlated EC, TDS, COD and BOD, $\mathrm{SO}_{4}^{2-}(\mathrm{p}<0.05)$. The $\mathrm{D}$ Index is significantly correlated only with $\mathrm{pH}$ and TDI is significantly correlated only with $\mathrm{T}^{\circ} \mathrm{C}$. According to other indices, such as $\mathrm{H}, \mathrm{N} 2, \mathrm{D}_{\mathrm{Ma}}, \mathrm{D}_{\mathrm{Me}}$, IBD and IPS, the level of correlation is high but not significant. All the samples are correlated with each other with strong and moderate correlations except $\mathrm{D}_{\mathrm{Ma}}$ and
$\mathrm{D}_{\mathrm{Me}}$ indices, where weak correlations with physical-chemical parameters can be found.

The correlations ranged from $0.721-0.843$ $(p<0.05$ and $p<0.01$ ), the weakest correlation was between $\mathrm{D}_{\mathrm{Me}}$ and $\mathrm{SO}_{4}$.

\section{CONCLUSIONS}

From eight monitoring stations in the Basin of Lepenci River, a diverse composition of 139 diatom species was obtained. It was observed that the upper part of the river stream was richer in species number. The monitoring stations located in the lower and middle part of the river stream were characterized with relatively smaller number of diatoms species present. On the basis of different indices (BD, IPS, IDG, Descy, Sla, IDSE, IDAP, EPID, CEE, WAT, TDI, IDP and SHE) that were taken into account, the best water quality was observed in monitoring stations of Prevallë (SP-1) and Jezerc (SP-2), where the water quality belongs to the first class. In other monitoring stations (SP-3 to SP-8) the water quality varied from the second (II) to the fourth (IV) class. 


\section{Acknowledgements}

The authors would like to express their gratitude for support to Naim Berisha colleague from Department of Biology, University of Pristina.

\section{REFERENCES}

1. Àcs, É., Szabó, K., Tóth, B., Kiss, K.T. 2004. Investigation of benthic algal communities, especially diatoms of some Hungarian streams in connection with reference conditions of the water framework directives. Acta Botanica Hungarica. 46, 255-277.

2. Anonymous 2010. The State of Water Report for Kosovo (MESP) Pristina. Municipality of Development Plan, City of Kaçanik, pp. 180.

3. Antonelli, M., Wetzel, C. E., Ector, L., Teuling, A. J., \& Pfister, L. 2017. On the potential for terrestrial diatom communities and diatom indices to identify anthropic disturbance in soils. Ecological Indicators, 75, 73-81. doi:10.1016/j.ecolind.2016.12.003

4. Bere, T. and Tundisi, J.G. 2010. Influence of ionic strength and conductivity on benthic diatom communities in a tropical river (Monjolinho), São Carlos-SP, Brazil. Hydrobiologia, 661(1), 261-276. doi:10.1007/s10750-010-0532-0

5. Besse-Lototskaya, A., Verdonschot, P. F., Coste, M., \& Vijver, B.V. 2011. Evaluation of European diatom trophic indices. Ecological Indicators, 11(2), 456-467. doi:10.1016/j.ecolind.2010.06.017

6. Blanco, S., Cejudo-Figueiras, C., Tudesque, L., Bécares, E., Hoffmann, L., \& Ector, L. 2012. Are diatom diversity indices reliable monitoring metrics? Hydrobiologia, 695(1), 199-206. doi:10.1007/ s10750-012-1113-1

7. Cantonati, M., Kelly, M.G. \& Lange-Bertalot, H. 2017. Freshwater benthic diatoms of Central Europe: over 800 common species used in ecological assessments. English edition with updated taxonomy and added species. Schmitten-Oberreifenberg: Koeltz Botanical Books. pp. 942, 135 pls.

8. Cemagref 1982. Etude des methodes biologiques quantitatives d'appreciation de la qualite des eaux . Rapport Division Qualite des Eaux Lyon - Agence financiere de Bassin Rhone-Mediterranee-Corse, Pierre-Benite, pp. 28.

9. Cemagref 1982. Etude des méthodes biologiques d'appréciation quantitative de laqualité des eaux. Cemagref, Division Qualité des Eaux, Lyon, pp. 218.

10. Coste, M., S. Boutry, J. Tison-Rosebery, F. Delmas 2009. Improvements of the Biological Diatom Index (BDI): description and efficiency of the new version (BDI-2006). Ecological Indicators 9, 621-650.
11. Dalu, T., Bere, T., Froneman, P.W. 2016. Assessment of water quality based on diatom indices in a small temperate river system, Kowie River, South Africa. Water SA, 42(2), 183. doi:10.4314/wsa.v42i2.02

12. Dell'Uomo, A. 2004. L'indice Diatomico di Eutrofizzazione / Polluzione (EPI-D) ne Monitoraggio Delle Acque Correnti. Lineeguida. A.P.A.T.A.R.P.A.T., pp. 101.

13. Descy J.P. and Coste M. 1991. A test of methods for assessing water quality based on diatoms. Verh. Internat. Limnol. 24, 2112-2116.

14. Descy, J.P. 1979. A new approach to water quality estimation using diatoms. Nova Hedwigia, 64, 305-323.

15. Gómez, N. and Licursi, M. 2001. The Pampean Diatom Index (IDP) for assessment of rivers and streams in Argentina. Aquatic Ecology 35, 163-181.

16. Hassan, F.M. and Shaawiat, A.O. 2015. Application of diatom indices in lotic ecosystem, Iraq. Global Journal of bioscience and biotechnology. 4(4), 381-388.

17. Hill, B.H., R.J. Stevenson, Y. Pan, A. T. Herlihy, P. R. Kaufmann, C.B. Johnson. 2001. A comparison of correlations between environmental characteristics and stream diatom assemblages characterized at genus and species levels. Journal of the North American Benthological Society 20, 299-320.

18. Hofmann, G., Werum, M., Lange-Bertalot, H. 2013. Diatomeen im Süßwasser - Benthos von Mitteleuropa. Bestimmungsfl ora Kieselalgen für die ökologische Praxis. Koeltz Scientifi Books, Königstein.

19. Jüttner, I., Chimonides, P.J., Ormerod, S.J. 2012. Developing a diatom monitoring network in an urban river-basin: Initial assessment and site selection. Hydrobiologia, 695(1), 137-151. doi:10.1007/ s10750-012-1123-Z

20. Kahlert, M., and Rašić, I.S. 2015. Similar smallscale variation of diatom assemblages on different substrates in a mesotrophic stream. Acta Botanica Croatica, 74(2), 363-376. doi:10.1515/ botcro-2015-0021

21. Kelly, M.G. and Whitton, B.A. 1995. J. Appl. Phycol. 7, 433. https://doi.org/10.1007/BF00003802

22. Kelly, M.G. and Whitton, B.A. 1995. The Trophic Diatom Index: a new index for monitoring eutrophication in rivers. J. Appl. Phycol. 7, 433-444, DOI: 10.1007/BF00003802.

23. Kosovo Environmental Protection Agency, (2015). Report on the State of Water, Prishtina .

24. Krammer K. and Lange-Bertalot H. 1986. Bacillariophyceae 1. Teil: Naviculaceae. In: Süsswasserflora von Mitteleuropa (Ed. by H. Ettl, J. Gerloff, H. Heynig \& D. Mollenhauer), Vol. 2/1. G. Fischer, Stuttgart \& New York. pp. 876. 
25. Krammer, K. 2010. The genus Pinnularia. In: Diatoms of Europe. Diatoms of the European Inland Waters and Comparable Habitats. Vol. 1. LangeBertalot, H. (ed.). A.R.G. Gantner Verlag K.G. Ruggell.

26. Krammer, K. 2013. Cymbopleura, Delicata, Navicymbula, Gomphocymbellopsis, Afrocymbella Supplements to cymbelloid taxa. In: Diatoms of Europe. Diatoms of the European Inland Waters and Comparable Habitats. Vol. 4. Lange-Bertalot, H. (ed.). A.R.G. Gantner Verlag K.G. Ruggell.

27. Krammer, K. Cymbella. 2012. Diatoms of Europe. Diatoms of the European Inland Waters and Comparable Habitats. Vol. 3. Lange-Bertalot, H. (ed.). A.R.G. Gantner Verlag K.G. Ruggell.

28. Kützing, F.T. 1845. Die Kieselschaligen Bacillarien oder Diatomeen. Nordhausen. Tab. 30. p. 152, Annals and Magazine of Natural History, 15(97), 185-188.

29. Lange-Bertalot, H. 1993. 85 Neue Taxa und über 100 weitere neu definierte Taxa ergänzend zur Süßwasserflora von Mitteleuropa, Bibliotheca Diatomologica, Vol. 2/1-4 (27), 1-45.

30. Lange-Bertalot, H. 1997. Frankophila, Mayamaea und Fistulifera. Drei neue Gattungen der Kasse Bacillariophyceae. Archiv für Protistenkunde 148 (1/2), 65-76.

31. Lange-Bertalot, H. 2001. Navicula sensu stricto. 10 Genera separated from Navicula sensu lato. Frustulia. Diatoms of Europe: diatoms of the European inland waters and comparable habitats. Vol. 2, pp. $1-526,140$ pls.

32. Lange-Bertalot, H., Bak M., Witkowski A., Tagliaventi N. 2011. Eunotia and some related genera. In: Diatoms of Europe. Diatoms of the European Inland Waters and Comparable Habitats. Vol. 4. Lange-Bertalot, H. (ed.). A.R.G. Gantner Verlag K.G. Ruggell.

33. Leclercq, L. and Lecointe C. 2008. Présentation de l'indice diatomique de saprobie-eutrophisation (IDSE) introduit dans la nouvelle version de Omnidia. 27ème Colloque de l'ADLaF Dijon 1-4 Sept. Livre des résumés. F. R. a. L. ECTOR. C23, 50.

34. Lecointe, C., Coste, M., Prygiel, J. 1993. OMNIDIA - a software for taxonomy, calculation of diatom indices and inventories management. Hydrobiologia, 269/270, 509-513.

35. Lecointe, C., Coste, M., Prygiel, J. 2003. OMNIDIA 3.2. Diatom index software including diatom database with taxonomic names, References and Codes of 11645 Diatom Taxa.

36. Leland H.V. 1995. Distribution of phytobenthos in the Yakima River basin, Washington, in relation to geology, land use, and other environmental fac-tors. Canadian Journal of Fisheries and Aquatic Sciences 52, 1108-1129.
37. Lenoir A. and Coste M. 1996. Development of a practical diatom index of overallwater quality applicable to the French Water Board network. In: Rott, E. (Ed.),Proceedings of International Symposium Use of Algae for Monitoring Rivers II.Institut für Botanik, Universität Innsbruck, 29-45.

38. Levkov Z. and Williams D.M. 2011. Fifteen new diatom (Bacillariophyta) species from Lake Ohrid, Macedonia. Phytotaxa 30, 1-41.

39. Levkov Z. 2009. Amphora sensu lato. In: Diatoms of Europe. Diatoms of the European Inland Waters and Comparable Habitats. Vol. 5. Lange-Bertalot H. (ed.). A.R.G. Gantner Verlag K.G. Ruggell, pp. 916.

40. Levkov, Z., Krstic, S., Metzeltin, D., Nakov, T. 2007. Diatoms of Lakes Prespa and Ohrid (Macedonia). Iconographia Diatomologica 16: 1-603. A.R.G. Gantner Verlag K.G.

41. Levkov, Z., Metzeltin, D.. Pavlov, A. 2013. Luticola and Luticolopsis. In: Diatoms of Europe. Diatoms of the European inland waters and comparable habitats. Volume 7. (Lange-Bertalot, H. Eds), pp. 1-698. Königstein: Koeltz Scientific Books.

42. Levkov, Z., Mitic-Kopnja, D., Reichardt, E. 2016. The genus Gomphonema in The Republic of Macedonia. Diatoms of the European Inland waters and comparable habitats 8: 1-552. Koeltz Scientific Books.

43. Lobo EA, Callegaro VL, Bender P. 2002. Utilização de algas diatomáceas epilíticas comoindicadoras da qualidade da águaem rios e arroios da Região Hidrográfica do Guaíba, RS, Brasil. Santa Cruz do Sul, Brazil: Edunisc (in Portuguese).

44. Lobo, E.A., Heinrich, C. G., Schuch, M., Wetzel, C.E., Ector, L. 2016. Diatoms as bioindicators in rivers. In: River Algae. Springer International Publishing, 245-271. DOI: 10.1007/978-3-319-31984-111.

45. Margalef R. 1968. Perspectives in Ecological Theory. University of Chicago Press, Chicago, pp. 112.

46. Marinovic R. 1957. Prilog poznavanja epifilinih alga u vodama Grobovacko-Posavskog kanala. Glasnik prirodnjackok muzeja. Knjiga 10 Beograd.

47. Noga T, Kochman N, Peszek L, Stanek-Tarkowska J, Pajaczek A. 2014. Diatoms (Bacillariophyceae) in rivers and streams and on cultivated soils of the Podkarpacie region in the years 2007-2011. Journal of Ecological Engineering 15, 6-25.

48. Pavlov, A., Levkov, Z., Williams, D.M., Edlund M.B. 2013. Observations on Hippodonta (Bacillariophyceae) in selected ancient lakes. Phytotaxa 90, 1-53.

49. Pavlov, A., Levkov, Z., Williams, D.M., Edlund, M.B. 2013. Observations on Hippodonta (Bacillariophyceae) in selected ancient lakes. Phytotaxa 90, 1-53.

50. Prygiel, J., Carpentier, P., Almeida, S., Coste, M., Druart, J.-C., Ector, L., Guillard, D., Honoré, M.-A., 
Iserentant, R., Ledegenck, P., Lalanne-Cassou, C., Lesniak, C., Mercier, I., Moncaut, P., Nazart, M., Nouchet, N., Peres, F., Peeters, V. [more]. (2002). Determination of the biological diatom index (IBD NF T 90-354): results of an intercomparison exercise. Journal of Applied Phycology 14, 27-39.

51. Prygiel J. and Coste M. 1993. The assessment of water quality in the Artois-Picardie water basin (France) by the use of diatom indices. Hydrobiologia 269/270. 343-349, DOI: 10.1007/BF00028033.

52. Prygiel J. and Coste M. 2000. Guide méthodologique pour la mise en œuvre de l'Indice Biologique Diatomées.

53. Round F.E. 1991. Diatoms in river-monitoring studies. Journal of Applied Phycology 3, 129-145.

54. Round F.E. 1993. A review and methods for the use of epilithic diatoms for detecting and monitoring changes in river water quality. London: HMSO.

55. Rovira, L., Trobajo, R., Ibáñez, C. 2012. The use of diatom assemblages as ecological indicators in highly stratified estuaries and evaluation of existing diatom indices. Marine Pollution Bulletin, 64(3), 500-511. DOI: 10.1016/j.marpolbul.2012.01.005.

56. Rumeau A., and Coste M. 1988. Initiation systematics of freshwater diatoms for practical use in a generic diatomic index. Bulletin Francais de la Peche et de la Pisciculture 309, 1-69.

57. Shannon C.E. and Weaver W. 1949. The Mathematical theory of communications. University of Illionis Press, Urbana, pp. 117.

58. Simpson, E.H. 1949. Measurement of diversity. Nature, 163-188.

59. Sladecek, V. 1986. Diatoms as indicators of organic pollution. In Acta hydrochim. Hydrobiol., $14,555-566$.

60. Soltanpour-Gargari, A., Lodenius, M., Hinz, F. 2011. Epilithic diatoms (Bacillariophycae) from streamsin Ramsar, Iran. Acta Botanica Croatica. 70(2), 167-190.

61. Srivastava, P., Grover, S., Verma, J., Khan, A.S. 2017. Applicability and efficacy of diatom indices in water quality evaluation of the Chambal River in Central India. Environmental Science and Pollution Research, 24(33), 25955-25976. DOI: $10.1007 / \mathrm{s} 11356-017-0166-0$

62. Stevenson J. 2014. Ecological assessments with algae: A review and synthesis. J. Phycol. 50, 437-461.

63. The European Parliament and The Council of The European Union (2000). Directive 2000/60/EC of the European Parliament and of the Council of 23 establishing aframework for Community action in the field of water policy. Off. J. Eur. Union 327 (October), 1-73.

64. Trobajo, R., Sullivan, M.J. 2010. Applied diatom studies in estuaries and shallow coastal environments. In: Smol, J.P., Stoermer, E.F. (Eds.), The Diatoms: Applications for the Environmental and Earth Sciences, Second ed. University Press, Cambridge, 309-323.

65. Van Dam H., Mertens A., Sinkeldam J. 1994. A coded checklist and ecological indicator values of freshwater diatoms from the Netherlands. Netherlands Journal of Aquatic Ecology 28, 117- 133.

66. Vasiljević, B., Krizmanić, J., Ilić, M., Marković, V., Tomović, J., Zorić, K., Paunović, M. 2014. Water quality assessment based on diatom indices - small hilly streams case study. Water Research and Management 4, 31-35.

67. Winter J.G., Duthie H.C. 2000. Epilithic diatoms as indicators of stream total $\mathrm{N}$ and total P concentrations. J N Am Benthol Soc 19, 32-49.

68. Toman, M., Grošelj, A., Zelnik, I. 2014. The influence of selected factors on the distribution of epilithic diatoms in a torrential river the Kamniška Bistrica (Slovenia). Acta Botanica Croatica. 73, 447-463.

69. Chao, A. 1984. Non-Parametric Estimation of the Number of Classes in a Population. Scandinavian Journal of Statistics, 11, 265-270.

70. Odum, E.P. 1993. Dasar-dasar Ekologi. Terjemahan oleh Tjahjono Samingan dari buku Fundamentals of Ecology. Yokyakarta: Gadjah Mada University Press. 